The Geneva Papers on Risk and Insurance, 20 (No. 74, January 1995) 45-56

\title{
The European Single Insurance Market
}

\author{
by Mark J. Boléat*
}

\section{Introduction}

"The European Single Insurance Market has finally arrived, with implementation of the Third Directives on 1 July 1994. Trade Associations and legislators can now sit back and let insurance companies get on with putting the new freedoms to practical use."

My trade association, like I am sure most others, has a large number of domestic issues to deal with and it is very tempting to say "that's Europe out of the way, we can now get on with the real issues facing our members". The impressive list of Directives set out after this introduction certainly gives the impression that a great deal has been achieved and that there can be little left to do. But is this really the case? The answer must be "no", not because of any lack of diligence on the part of the European Commission or the insurance supervisors, but rather because of the nature of insurance itself.

Insurance is a very complex financial service, covering as it does a large number of different types of risk and having the potential to impact on every area of our lives. In turn, this means that virtually any proposals put forward by the European Commission have possible implications for insurers, who need to influence the debate, to remain on the alert to make sure that they are aware of new proposals and are able to submit their views at an early stage so that the implications can be properly considered and any necessary changes made before the proposals become set in stone. Three examples will serve to illustrate this point :

- All Member States' social security systems are experiencing financial difficulties and consideration is being given to ways in which expenditure can be cut back. This is an area where the private insurance sector can contribute constructively to the discussions by putting forward possible solutions, although care will need to be taken that governments do not simply try to pass the problems of poor risks and inadequate financing to the private sector.

- Pollution is becoming an ever-increasing problem as Member States struggle to cope with the need to clean up already polluted sites and attempt to prevent new pollution at an unacceptable level. An insurance market for gradual pollution will only develop very gradually and the European Union must take care to avoid the situation in the United States

\footnotetext{
* Director General, Association of British Insurers, London.
} 
where the attempt is being made to place the burden on the insurance industry by reinterpretation of policy documents and the Superfund proposals.

- The European Commission originally proposed long-term protection for the design of motor spare parts, not realising that this would effectively give motor manufacturers a monopoly and put up the cost of repairs. Insurers, through the CEA, together with consumers, have been successful so far in having the protection reduced to three years, although the battle has yet to be finally won. The original proposal could significantly have increased the cost of motor repairs and thus motor insurance.

Set out below are details of Directives directly or indirectly affecting insurance. These represent a remarkable achievement and provide a firm basis for the single market to develop. However, this development will only take place gradually, as insurers become geared up to providing policies designed to meet foreign policyholders' needs, both through local establishments and on a services basis, and as consumers become used to the idea of obtaining their insurance abroad. While this is taking place, what will there be for associations such as my own to do? The pace of new legislation will undoubtedly be slower, but there are still a number of important issues to be dealt with, some of which will influence the development of market capacity, as follows:

- Freedom for workers to be able to take their pensions with them when they go to work in other countries and, eventually, the possibility for pensions to be provided across borders;

- Harmonisation of measures for supervision of insurance groups and financial conglomerates, including measures to prevent double gearing;

- Review of the solvency margin requirements as required by the Third Directives;

- Measures to overcome the effects of the Bachmann case;

- Winding-up procedures for insurance companies.

Insurers will also need to monitor the operation of the single market in order to discuss practical difficulties and bring these to the attention of supervisors and the European Commission. The interpretation by Member States of "the general good" will be of particular importance and care will need to be taken that it is not used to reintroduce barriers swept away by the Third Directives. Intermediaries will have an important part to play in the new single market and it remains to be seen whether the implementation by Member States of the 1991 Recommendation (described below) will make it easier for intermediaries to smooth the path of insurers and policyholders wishing to take advantage of the new freedoms.

\section{Insurance directives}

\section{Reinsurance}

Directive 64/225, on freedom of establishment and services in the field of reinsurance and retrocession, abolished restrictions based on nationality on the freedom of individuals and companies to establish and provide services in reinsurance. Where an individual or a company is also engaged in direct insurance, that part of the business is excluded from the provisions of the Directive.

OJ 878/64 of 4.4.64, adopted on 25.2.64. 


\section{Non-life establishment}

This Directive, number $73 / 239$, relates to freedom of establishment for direct non-life insurance, and was issued in parallel with Directive 73/240 (the so-called "Suppression Directive") which removed restrictions on freedom of establishment for this type of insurance. The Directive was intended to facilitate freedom of establishment by coordinating the conditions relating to the taking up and pursuit of direct non-life insurance by undertakings whose head offices are situated within the Community and by agencies or branches of third country undertakings. The former must be officially authorised, adopt particular legal forms, submit a scheme of operations, hold certain technical reserves and maintain a solvency margin and guarantee fund. Branches and agencies of third country undertakings must be entitled to carry on insurance business under their own national law and must keep separate accounts, hold local reserves and maintain a solvency margin and guarantee fund.

OJ 1973 L228/3 and L228/20 of 16.8.73, both adopted on 24.7.73.

\section{Life establishment}

This Directive, number 79/267, is the equivalent for life insurance of the Non-Life Establishment Directive. It contained similar provisions and also provided that pre-existing composites (transacting both life and non-life business within one company) could continue, subject to rules on separate management, with a review of the operation of composite companies to be undertaken after ten years. As a result of this review, concluded in early 1991, the Commission included provisions in the draft Life Framework Directive to remove all restrictions on composite insurers. These provisions were amended in the final text of the Framework Directive.

OJ L63/1 of 13.3.79 adopted on 5.3.79.

\section{Community coinsurance}

Directive $78 / 473$ was intended to create true freedom of services in coinsurance as a first step towards freedom of services in non-life insurance as a whole. The risks to be freed were those "which by reason of their nature or size are liable to be covered by international coinsurance". Little use was made of the Directive because of differences of view as to whether the leading insurer must be established in the country of the risk, and as to the meaning of "nature or size".

In practice, the Directive has now been made redundant by the Non-Life Framework Directive.

OJ L 151/25 of 7.6.78, adopted on 30.5.78.

\section{Freedom of services for non-life insurance}

This Directive, number 88/357, was the second step (the Coinsurance Directive having been the first step) towards freedom of services for non-life insurance. The Directive introduced a freer regime for "large risks", with other ("mass") risks still being subject largely to the control of the host country.

One part of the Directive supplemented the Non-Life Establishment Directive, in particular by incorporating in that Directive a definition of "large risks" (marine, aviation and transport insurance, credit and suretyship insurance in the case of professional, industrial or commercial policyholders, and property, general liability and miscellaneous financial loss above thresholds which were halved from 1.1.93). 
Another part dealt specifically with freedom of services and provided that "large risks" could be written on a services basis subject only to various details, including solvency, being provided to the supervisory authority of the country of the risk. As regards "mass" risks, the Directive gave member states the option of requiring administrative authorisation before allowing undertakings from other member states to provide cover on a services basis for risks in their territory (only the UK and Netherlands decided not to require such authorisation).

Greece, Ireland, Spain and Portugal were allowed transitional arrangements for implementing the freer regime for large risks, although Ireland did not make use of this option. OJ L $172 / 1$ of 4.7.88, adopted on 22.6.88.

\section{Freedom of services for motor insurance}

This Directive, number 90/618, was adopted on 8 November 1990 and came into force on 20 November 1992. The Directive deleted the exclusion of motor third party liability insurance in the Non-Life Services Directive and also included motor insurance in the "large risks" regime of that Directive. This meant that risks above the thresholds already applicable to the property classes benefited from the more liberal regime applicable to large risks, while other risks, like other "mass" risks, were subject to administrative authorisation by the country of the service.

The Directive also required insurers writing motor insurance on a services basis to become members of the national Bureau and national Guarantee Fund of the country of the service. The member state of the service may require an insurer to nominate a local representative to be responsible for the handling and settlement of claims. The existence of such a representative cannot be deemed to equate to a branch or agency and will therefore not require the insurer to be established in the country of the service.

OJ L330/44 of 29.11.90, adopted 8.11.90.

\section{Freedom of services for life insurance}

This directive, number 90/619, was adopted on 8 November 1990 and came into force on 20 May 1993.

The Directive supplemented the Life Establishment Directive of 1979, in particular as regards choice of law, transfers of portfolios between different insurance companies, and reciprocity with third countries. It also contained provisions relating to freedom to provide services, and in this connection distinguished between passive (own initiative) business, where the proposer takes the initiative in approaching an insurer in another country, and active business, where the insurer actively seeks business in other countries.

Unlike the Life Establishment Directive, the Directive did not apply to certain types of business, notably pension fund management.

Like the Non-Life Services Directive, the Directive provided a freer regime for risks where the policyholder was deemed to require less protection, but in this Directive the distinction was not between large and mass risks but between own initiative and active business. For own initiative business, insurers were only required to notify the host country of their intention to write the business, and approval of rates and conditions by the host country was not allowed. For active business member states could require insurers to be authorised by the host country and could also require rates and conditions to be approved. Composite insurers (writing both life and non-life business) were permitted to write own initiative 
business and also active business if permitted at the time the Directive was notified in a particular member state, and in the other member states until 31 December 1995 (provisions to remove the restrictions under this Directive and the Life Establishment Directive were included in the Life Framework Directive).

The Directive allowed Greece, Spain and Portugal to restrict services business to own initiative business for certain periods and to apply their own legislation to technical reserves during these periods. The Directive also provided the following options for all the member states, although these were overtaken by the Life Framework Directive, which came into force on 1 July 1994 :

- prohibition of own initiative business, until 31.12.94, in respect of group insurance contracts entered into by virtue of the insured person's contract of employment or professional activity;

- prohibition of use of local intermediaries for own initiative business, for up to three years from the coming into force of the Directive (until 20 May 1996).

OJ L 330/50 of 29.11.90, adopted 8.11.90.

\section{Non-life framework directive}

The Directive was adopted in June 1992 and came into force in July 1994. It introduces the single licence for non-life business, which means that the head office supervisor of an insurer is responsible for the financial aspects of regulation (solvency margin and technical reserves) not only in respect of the head office but also as regards branches in other countries and cross-border ("services") business.

In addition, the Directive contains the following provisions:

- Because it has not been possible to reach agreement on the draft Insurance Contract Law Directive, the Commission have given up the idea of co-ordinating insurance contract law and have instead retained the choice of law provisions of the 1988 Non-Life Services Directive. These are based on the principle of the country of risk law applying for mass risks. However, the complete freedom of choice of law allowed for marine, aviation and transport insurance has been extended to "large risks" as defined by the Non-Life Services Directive.

- Abolition of approval of rates and conditions. Instead, the host member state may require non-systematic notification of conditions after the insurer has started to write business there, with advance systematic notification for compulsory insurance and health insurance issued as a substitute for social security.

- Freedom to localise technical reserves anywhere in the Community, and alteration of the matching rules in the Non-Life Services Directive to allow $100 \%$ matching in ECU.

- Harmonisation of cover for technical reserves on the basis of a list of permitted assets and with member states not being able to require investment in particular types of asset.

OJ L228/1 of 11.8.92, adopted 18.6.92.

\section{Life framework directive}

The Directive was adopted on 10 November 1992 and came into force in July 1994 like the Non-Life Framework Directive. Unlike the Life Services Directive it applies to all the types of business covered by the Life Establishment Directive. Most of the provisions are 
virtually identical to those in the Non-Life Framework Directive, but the Directive has additional provisions for life insurance covering the following:

- Actuarial principles for calculating technical reserves based on proposals by the EC Consultative Group of Actuaries;

- Disclosure of information to the policyholder before the contract is signed and also during the term of the contract;

- A cooling-off period of 14-30 days. This now applies to establishment business (the Life Services Directive introduced it for services business only);

- Matching rules similar to those for non-life insurance in the Non-Life Services Directive. These do not apply to unit-linked contracts.

The original draft also included provisions lifting all the restrictions on composite insurers in the Life Establishment and Life Services Directives. However, the final text contains provisions which allow complete freedom of establishment and services for existing composites but which only allow new composites to a limited extent. Life insurers can seek authorisation to write health and accident insurance as main classes, rather than as ancillary business as is the case at present. Non-life insurers authorised solely to write health and accident insurance can also seek authorisation for long-term business, which will allow them to write long-term permanent health insurance (at present non-life insurers may only issue contracts for periods of up to five years).

OJ L 360/1 of 9.12.92, adopted 10.11.92.

\section{Legal expenses insurance}

This Directive, number 87/344, was adopted in June 1987 and came into force in June 1990. It removes the provision in the Non-Life Establishment Directive that allows Germany to maintain its system of requiring legal expenses insurance companies to write no other classes of business. The text is based on a compromise solution which allows specialist and composite insurers to operate side by side subject to the safeguards of free choice of lawyer for the insured, separate management and accounting by composite companies writing this class, and the ability for member states to require composite companies to channel legal expenses claims through a separate organisation (in this context, "composite" means writing more than one kind of non-life insurance). The free choice of lawyer for the insured is intended to reduce to a minimum the possibility of conflicts of interest where a policyholder has more than one policy, e.g. legal expenses and motor, with the same company.

OJ L 185/77 of 4.7.87, adopted 22.6.87.

\section{Credit insurance}

This Directive, number 87/343, was adopted in June 1987 and came into force in June 1990. It is similar to the Legal Expenses Insurance Directive in that it abolishes the specialisation requirement in Germany for credit and suretyship insurance. The text contains additional safeguards for credit insurance, these being mainly additional financial requirements. Insurers must keep separate accounts and maintain a higher guarantee fund than previously, and are required to set up equalisation reserves for the purpose of offsetting any technical deficit or above-average claims ratio. Export credit insurance "for the account of or guaranteed by the state, or where the state is the insurer" is excluded pending further coordination.

OJ L185/72 of 4.7.87, adopted 22.6.87. 


\section{Assistance}

This Directive, number 84/641, brings assistance activities within the scope of the 1973 Non-Life Establishment Directive as a new class 18. It provides for freedom of establishment of undertakings wishing to carry out assistance business and lays down a framework for member states to supervise the financial soundness of these undertakings by requiring the maintenance of solvency margins and permitting checks to be made on their resources. The Directive had to be in force by January 1988.

OJ L 339/21 of 27.12.84, adopted on 10.12.84.

\section{Motor insurance}

Directive 72/166, known as the "Green Card" Directive, abolished the checking of green cards at frontiers between EU member states and other countries which agreed to implement the provisions of the Directive. Policies must give the minimum compulsory cover in all the countries which apply the Directive.

A second Directive on third party motor insurance, number $84 / 5$, was adopted at the end of 1983. This supplemented the 1972 Directive, as follows:

(a) Compulsory insurance must cover not only bodily injury but also property damage ;

(b) Liability must be covered up to certain minimum limits;

(c) Compensation must be guaranteed up to the minimum limits in the case of uninsured or unidentified vehicles;

(d) Insurers must not exclude members of the family of the policyholder, of the driver or of any other person responsible for the accident from the cover they give.

The Directive had to be implemented by the end of 1988 but longer periods were provided for Greece, Ireland and Italy.

A third Directive on motor insurance adopted on 14 May 1990, number 90/232, is intended to resolve certain problems arising in some of the member states which result from or were left unresolved by the first and second Directives on motor insurance. The first aim is to ensure that all passengers, other than the driver and passengers who have knowingly and willingly entered a stolen vehicle, should be covered for personal injury by compulsory third party insurance. The second aim is to implement fully the objective of the first Directive that all third party motor insurance policies should provide at least the minimum cover required by law in all the member states. The Directive had to be implemented by 31 December 1992, but transitional arrangements applied to Greece, Ireland, Spain and Portugal.

OJ L 103/1 of 2.5.72 (adoption date 24.4.72), OJ L 8/17 of 11.1.84 (adoption date 30.12.83) and OJ L129/33 of 19.5.90 (adoption date 14.5.90).

\section{Insurance accounts directive}

The Directive was adopted on 19 December, 1991 and will first affect insurers in respect of their financial year beginning on 1 January 1995 or during the calendar year 1995. It covers the layout of the balance sheet and profit and loss accounts and contains rules for the valuation of assets. It is considered to provide sufficient harmonisation for non-life insurance as regards the definition and calculation of technical reserves, but the Life Framework Directive supplements this Directive by provisions on calculation of technical reserves for life insurance.

OJ L 374/7 of 31.12.91, adopted 19.12.91. 


\section{Insurance Committee}

A Directive was adopted on 19 December, 1991 which sets up a new Insurance Committee. The Committee is responsible for operating the reciprocity rules in the insurance sector and also for technical work such as occasional adaptations to the rules governing the composition of technical reserves. In addition, the Committee acts as a forum where there can be discussion of general policy issues affecting the insurance sector and which allows the national supervisory authorities to develop close ties and closer working relationships.

OJ L374/32 of 31.12.91, adopted 19.12.91.

\section{Insurance intermediaries}

Directive 77/92 sought to facilitate the practical exercise of freedom of establishment and services for insurance brokers and agents by laying down objective standards of training, experience and good repute which the regulating authorities in a member state must accept as sufficient qualification for nationals from other member states to practise there.

The Directive has been supplemented by a Recommendation adopted by the Commission in December 1991. The Recommendation is intended to encourage those member states which do not already regulate insurance intermediaries to do so and other member states to amend existing provisions to bring them closer together. It contains the following provisions:

- It applies to independent intermediaries, agents and sub-agents, i.e. those intermediaries covered by the 1977 Intermediaries Directive;

- The management of an undertaking acting as an insurance intermediary must include an adequate number of persons possessing general, commercial and professional knowledge and ability. It is recommended that member states should ensure that such undertakings offer relevant basic training for employees involved in selling insurance products;

- Independent intermediaries must disclose to proposers any direct legal or economic ties to an insurance undertaking which could affect their choice of undertaking, and must also notify a competent body in their member state of the spread of business with different insurance undertakings over the previous year;

- Intermediaries are required to possess general, commercial and professional knowledge and ability, with it being up to member states to lay down different levels of such knowledge and ability for different categories of intermediary. In the case of agents, member states can allow these levels to be determined and administered by insurance undertakings which assume responsibility for their agents :

- Intermediaries must possess professional indemnity cover or a comparable guarantee against liability arising from professional negligence;

- An insurance intermediary must be of good repute and shall not previously have been declared bankrupt unless he has been rehabilitated in accordance with his national law;

- Member states may require independent intermediaries to have sufficient financial capacity, with the level and form of capital being determined by the member states;

- Intermediaries must be registered, but agents can be included on individual company registers;

- Member states must ensure there are adequate sanctions which can be applied to any person acting as insurance intermediary without being registered or who does not comply with other requirements of the Recommendation.

OJ L26/14 of 31.1.77, adopted on 13.12.76, and OJ L19/32 of 28.1.92, adopted on 18.12.91. 


\section{Other directives affecting insurance}

\section{Products liability}

This Directive, number 85/374, which was adopted in July 1985, makes a producer liable for damage resulting from a defective product regardless of fault, providing that the victim can prove that there has been a defect and can establish a causal link between the defect and the injury suffered (strict liability). Injured parties can bring claims against a manufacturer of a product or if necessary against the supplier. The main features of the Directive, apart from the introduction of strict liability, are as follows:

(a) Provision is included for a development risks defence, but member states had the option of retaining or introducing legislation which does not permit such a defence ;

(b) There is a limitation period of three years for proceedings for the recovery of damages. The timing runs from the day on which the plaintiff becomes aware, or should reasonably have become aware, of the damage, the defect and the identity of the producer;

(c) The rights conferred upon injured people are extinguished upon the expiry of a period of ten years from the date on which the producer put into circulation the product which caused the damage;

(d) There are no financial limits in the Directive, but member states had the option of imposing a limit of not less than 70 million ECU.

OJ L 210/29 of 7.8.85, adopted 25.7.85.

\section{Capital movements}

Directives were adopted in November 1986 and June 1988 on the liberalisation of capital movements. They amended the previous, 1960 Directive by removing several of the exemptions in that Directive which had severely limited its practical effects. The 1960 Directive liberalised premiums and payments in respect of life assurance, premiums and payments in respect of credit insurance and other capital transfers in respect of insurance contracts, but not the capital of insurance companies. The 1986 Directive liberalised movements of capital in respect of unit trusts and other mutual funds and also the purchase and sale of unlisted securities.

The 1988 Directive removed controls on all capital movements. It entered into force in eight member states on 1 July 1990, but Greece, Ireland, Portugal and Spain were allowed transitional arrangements until the end of 1992.

Directive 86/566, adopted 17.11.86, OJ L 332/22 of 26.11.86; Directive 88/361, adopted 24.6.88, OJ L 178/5 of 8.7.88.

\section{Jurisdiction and the enforcement of judgements}

A Convention on Jurisdiction and the Enforcement of Judgements was agreed by the original six member states in 1968 and amended following the accession to the EC of Denmark, Ireland and the UK in 1973. The Convention lays down common rules of jurisdiction and standardises the procedures for obtaining enforcement of judgements.

There is a special section on insurance, dealing with the courts in which insurers can be sued and agreements on jurisdiction between insurers and policyholders. The basic principle as regards jurisdiction is that an insurer in a Contracting State can be sued in the country where he is domiciled or the country where the policyholder is domiciled. The insurer can bring proceedings only in the country of the defendant, irrespective of whether the defendant is the policyholder, the insured or a beneficiary. 
Exemptions from these principles include cases where an agreement on jurisdiction is entered into after a dispute has arisen or where the agreement allows the policyholder, the insured or a beneficiary to bring proceedings in a country other than his country of domicile. If the insurer and the policyholder, at the time of conclusion of the contract, are both domiciled or habitually resident in the same country, an agreement on jurisdiction can confer jurisdiction on the courts of that country even if the harmful event occurs in another country, provided that the agreement is not contrary to the law of the country in which the insurer and policyholder are domiciled. A general exemption is permitted for marine and aviation insurance (material damage).

The amended Convention has only been in effect from 1 January 1987 because it needed to be ratified by all six original member states and one of the other member states. The amended Convention was published in OJ C97/2 of 11.4.83.

\section{Convention on the law applicable to contractual obligations}

This Convention, known as the Rome Convention, applies to contractual obligations in any situation involving a choice between the laws of different countries. It was signed on 19 June, 1980 and is now applicable in all twelve member states following the signature of a further Convention relating to the adherence of Spain and Portugal on 18 May 1992. The Convention does not apply to direct insurance contracts covering risks situated in the Community, which are governed by the provisions on choice of law in the Non-Life Services Directive (as amended by the Non-Life Framework Directive) and the Life Services Directive. It does, however, apply to reinsurance contracts.

OJ 1980 L266/1, initialled on 19.6.80.

\section{UCITS}

Directive 85/611 of 20 December 1985 (as amended by Directive 88/220 of 22 April 1988 ) on the coordination of laws, regulations and administrative provisions relating to undertakings for collective investment in tranferable securities (UCITS) came into force on 1 October 1989, although Greece and Portugal were allowed to defer implementation until 1 April, 1992.

The purpose of the Directive is to enable investment products falling within the scope of the Directive to be promoted and sold throughout the Community. The Directive applies only to open-ended unit trusts which invest principally in transferable securities listed on recognised stock exchanges. Other types of unit trusts, commonly referred to as nonUCITS, are not covered.

OJ L375/3 of 31.12.85, adopted 20.12.85.

\section{Money laundering}

This Directive was adopted on 10 June, 1991 and came into force on 1 January, 1993. It is designed to prevent the use of financial institutions for the laundering of monies derived from serious crime. It applies only to life insurance, not non-life insurance. The Directive requires member states to prohibit money laundering; credit and financial institutions to require identification of their customers when entering into business relations, and cooperation by such institutions with the authorities responsible for combating money laundering, in particular by notifying them of any facts which might be an indication of money laundering. 
As regards insurance, the identification requirements apply where the periodic premium amount (or amounts) to be paid in any given year exceeds $1,000 \mathrm{ECU}$ or where a single premium exceeds 2,500 ECU. However, premium payments by cheque or bank transfer through an EU credit institution can be exempted from the identification requirements at the option of member states.

OJ L166/77 of 28.6.91, adopted on 10.6.91.

\section{Public procurement directives - services}

At the end of 1990, the Commission decided to extend the existing works and supplies Directives to the purchase of services, and two Directives were prepared, one covering local authorities and the other utilities. The Directives are horizontal ones covering the procurement of all services rather than being aimed at particular types of services. The procurement of insurance is covered, together with procurement of the services of insurance intermediaries.

The Local Authorities Directive was adopted in June 1992 and came into force on 1 July 1993. The Directive relating to utilities (public entities in the energy, water, transport and telecommunications sectors, together with private sector bodies which possess special or exclusive rights) was adopted on 14 June 1993 and came into force on 1 July 1994.

OJ L209/1 of 24.7.92 and L199/84 of 9.8.93.

\section{Investment services and capital adequacy directives}

The Investment Services Directive is intended to introduce the single licence for investment firms, while the Capital Adequacy Directive lays down initial capital requirements for investment firms, including intermediaries who sell and advise on investments. The Capital Adequacy Directive was adopted on 15 March 1993 and the Investment Services Directive on 10 May 1993. Both will come into force at the end of 1995.

The Investment Services Directive excludes the following:

- Independent intermediary firms "which may not hold clients' funds or securities and which for that reason may not at any time place themselves in debit with their clients" and who place orders only with investment firms/credit institutions authorised under EC Directives or branches of third country firms or institutions which comply with prudential rules at least as stringent as those laid down by the EC Directives. Such firms will not benefit from the single passport but will also not be subject to the capital requirements of the Capital Adequacy Directive.

- Tied agents who act exclusively on behalf of and under the responsibility of an investment firm, because their operations are considered to be the operations of the investment firm itself. Such agents will therefore benefit from the single passport to the extent that their principal benefits from it.

OJ L 141/27 of 11.6.93 and L141/1 of 11.6.93.

\section{Directive on unfair contract terms}

Insurers sought to have the "core provisions" of insurance contracts (which define the risk) excluded from this Directive, on the grounds that it is more suited to goods than 
services and would have serious implications for insurance underwriting. The final text, which was adopted on 5 April 1993 and comes into force at the end of 1994, contains a recital stating that "assessment of the unfair character of terms must not relate to the main subject-matter of the contract nor to the quality/price ratio of the goods or services supplied; it follows that, as regards insurance contracts, terms which clearly define or circumscribe the insured risk and the insurer's liability shall not be subject to such assessment since these restrictions are taken into account in calculating the premium paid by the consumer".

OJ L95/29 of 21.4.93 adopted 5.4.93. 